Nenhuma Comissão promotora de uma iniciativa poderá alguma vez sentir-se absolutamente satisfeita com os resultados alcançados. Assim, ainda que o saldo global tivesse sido significativamente positivo, há que arranjar no futuro estratégias mais eficazes, para uma maior mobilização dos empresários da região para este tipo de iniciativas.

António Rafael Amaro

\title{
ESTÁGIOS NO ANO LECTIVO 1995/96
}

Dá-se aqui continuidade ao já referido nos n. ${ }^{\text {s }} 2$ (1993, p. 143-148) e 3 ( 1994 , p. 195-197) desta revista. O esforço de gestão do estágio integrado na Licenciatura, levado a cabo pelo I.U.D.P.S., tem sido conseguido, graças à colaboração de todos os docentes, ao corpo de supervisores e aos responsáveis pela gestão das organizações económicas e sociais. Estes não só permitiram a integração do(s) aluno(s) como também desempenharam um papel fundamental na orientação dos seus trabalhos, em articulação com o supervisor de cada estagiário.

No ano lectivo de 1995/96 realizaram o seu estágio 83 alunos do 5. ${ }^{\circ}$ ano da Licenciatura em Gestão e Desenvolvimento Social.

Para o efeito conta-se com a colaboração de 71 organizações económicas e sociais, tendo sido, no entanto, disponibilizados 109 lugares de estágio.

\section{Gráfico I}

\section{Centros de Estágio no Ano Lectivo de 1995/96}

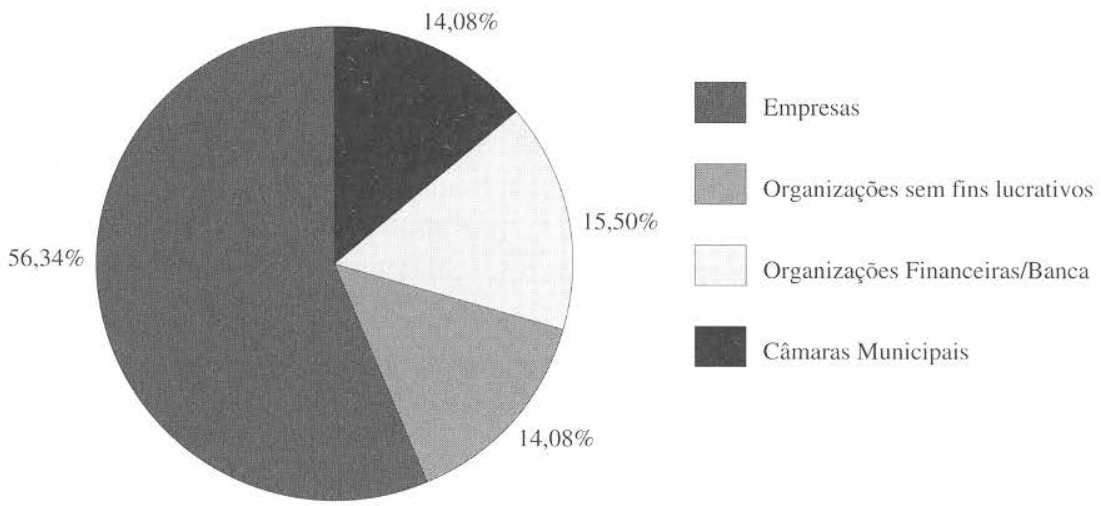

Fonte: Dados do Processo de Estágios do Ano Lectivo de 1995/96 
Pela análise do Gráfico I, podemos verificar que 56,34\% das organizações que estão a colaborar na integração dos estagiários são Empresas; 14,08\% são Organizações sem Fins Lucrativos; 15,50\% são organizações Financeiras/Banca e os restantes 14,08\% são Câmaras Municipais. É importante salientar, relativamente aos anos anteriores, o aumento de estágios a decorrer em organizações Financeiras/Banca.

\section{Gráfico II}

Localização dos Centros de Estágio do Ano Lectivo de 1995/96

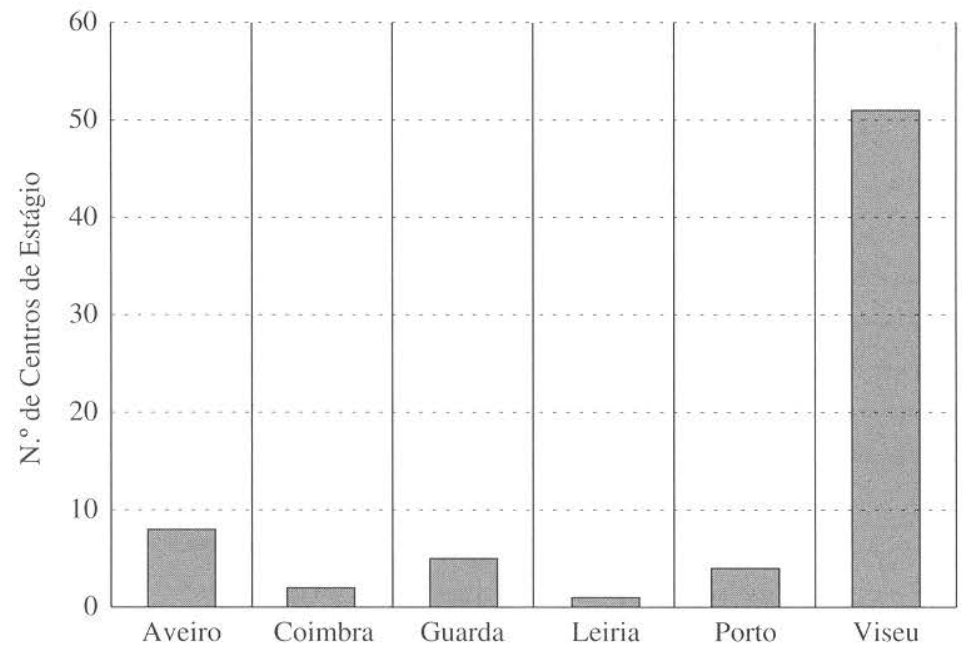

Fonte: Dados do Processo de Estágios do Ano Lectivo de 1995/96

Tal como podemos verificar pela análise do Gráfico II, nem todos os Centros de Estágio se localizam no distrito de Viseu.

Neste ano lectivo, os centros de estágio distribuem-se pelos distritos de Aveiro $(11,27 \%)$, Coimbra $(2,82 \%)$, Guarda $(7,04 \%)$, Leiria $(1,41 \%)$, Porto $(5,63 \%)$ e Viseu $(71,83 \%)$.

São sobretudo empresas industriais que colaboram com o I.U.D.P.S., para proporcionarem aos estagiários contacto com a realidade profissional, onde futuramente se irão inserir.

O estágio anual termina com a apresentação pública, perante um júri, do relatório elaborado pelo aluno, em função do trabalho realizado. 